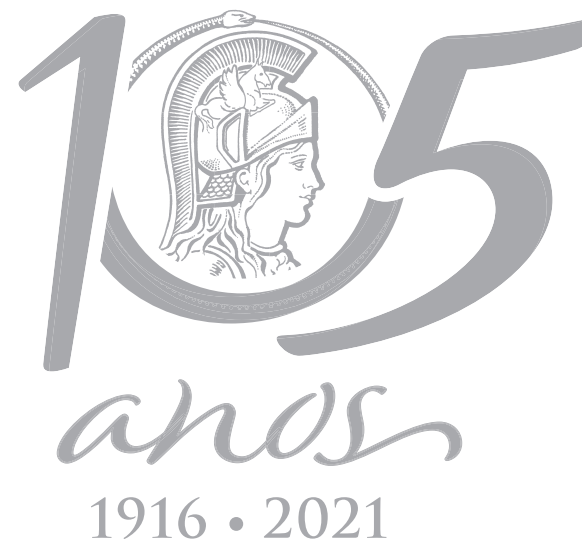

$1916 \cdot 2021$

\title{
Constitutionality analysis of amendments to the Protocol on Environmental Protection on the Antarctic Treaty Annexes
}

\author{
LEO EVANDRO FIGUEIREDO DOS SANTOS
}

\begin{abstract}
Antarctic environmental and climatic conditions have repercussions in Brazil and South America and are a central focus of concern as their balance may be affected. Therefore, legal instruments of environmental protection such as the Protocol on Environmental Protection to the Antarctic Treaty are fundamental. To streamline its application, the Protocol foresees accelerated mechanism for the approval and entry into force of "Measures" that modify provisions in its Annexes. This basis makes it unnecessary to submit amendments to domestic processes of international treaties approval in member countries of the Antarctic Treaty - in the case of Brazil, National Congress approval. This could give rise to a violation of Articles 49, item I, and 84, item VIII, of the 1988 Brazilian Constitution. This paper claims that there is no violation. This conclusion was based on an approach that supports constitutionality based on formal foundations and interpretation of the law, so that, mainly, the provisions and norms arising therefrom are understood in the context of Executive Agreements. The methodological construction is supported by the deductive method and assumes that the research hypothesis is controlled.
\end{abstract}

Key words: Antarctic, Constitutionality, Madrid Protocol, Treaties.

\section{INTRODUCTION}

This paper aims to verify the constitutionality of provisions and norms issued with basis on Article 9, paragraph 3, to the Protocol on Environmental Protection on the Antarctic Treaty (hereafter PEPAT), as well as its Annex I, Article 8, Annex II, Article 9, Annex III, Article 13, Annex IV, Article 15, Annex V, Articles 6, 8, and 12 and Annex $\mathrm{VI}$, Article 13, against the provisions of Articles 49, item I, and Article 84, item VIII, of the 1988 Constitution of the Federative Republic of Brazil'.

1 The PEPAT (also known as Madrid Protocol) was adopted in 1991 by the XI-4 Special Antarctic Treaty Consultative Meeting, in Madrid, and came into force in 1998. Annexes I to IV on the Protocol were signed in 1991, and also came into force in 1998. Annex V was signed at the XVI ATCM, in Bonn, Germany (1991) and came into force in Brazil along
The Antarctic Treaty (AT, Article 9, paragraph 1) and PEPAT (Article 9, paragraph 3) allow the Antarctic Treaty Consultative Meeting (ATCM) to elaborate rules for PEPAT's Schedule and Annexes, among which are so-called 'Measures'. Under the Antarctic Treaty System (ATS), Measures have a binding effect on States Parties ${ }^{2}$. As a general rule defined in Article 9 (4)

with the Protocol and the other Annexes. Annex VI, which attends to environmental liability in the Antarctic region, was approved by Measure 1 (2005) at the XXVIII ATCM in Stockholm and is not yet into force because some Consultative Parties, such as Brazil, have not ratified it domestically so far. The PEPAT and its Annexes are available at: https://www.ats.aq/e/ key-documents.html. Accessed on Jan. $24^{\text {th }}$ 2021. PEPAT's Schedule, which attends to its arbitration (for dispute settlement), establishes in its Article 13 that amendments and modifications in its text shall be deemed to have been approved, unless a measure specifies otherwise, one year after its adoption.

2 According to Decision 1 of ATCM XIX, which took place in Seoul in 
of the AT, Measures come into force after being approved by States Parties. It occurs that the regulations cited above establish the possibility that they become effective on an accelerated basis when elaborated in order to modify or amend PEPAT's Annexes, needless for them to be submitted to their respective ATS member countries' domestic processes of international treaties approval - in the case of Brazil, National Congress approval. Specifically, Article 9 (3) of the PEPAT is the provision that allows for an accelerated basis. Annex I (Article 8), Annex II (Article 9), Annex III (Article 13), Annex IV (Article 15), Annex V (Article 12), and Annex VI (Article 13), in turn, effectively establish that amendments or modifications to the PEPAT's Annexes to become effective one year after the close of the ATCM at which they were adopted. Particularly, in Annex V, Articles 6 and 8 establish that in cases of proposed protection and management plans and sites or monuments of recognized historic value, norms are to become effective 90 days after the close of the ATCM at which they were adopted. These PEPAT provisions could be in conflict with the stated in the aforementioned provisions of the Brazilian Constitution, which in summary establish that the entry into force of an international treaty at the domestic level depends on approval from the National congress.

In this article, the Protocol's norms under analysis are considered constitutional. Constitutionality is supported from a formal interpretative and argumentative approach within the scope of legal science, which justifies their constitutionality, especially considering PEPAT's approval by the National Congress and the possibility of it receiving amendments and modifications as Executive Agreements

1995, a "text which contains provisions intended to be legally binding once it has been approved by all the Antarctic Treaty Consultative Parties will be expressed as a Measure recommended for approval in accordance with paragraph 4 of Article IX of the Antarctic Treaty and referred to as a 'Measure'". Available at: http://www.ats.aq/devAS/ats_ meetings_meeting_measure.aspx?lang=e. Accessed on Sept. $4^{\text {th }} 2015$.
$(\mathrm{EAs})^{3}$. This premise requires assuming that the research hypothesis is controlled. Thus, the arguments that give basis to constitutionality will be explored and the variables that make the intended result unfeasible will be rejected, in which sense the hypothesis is subject to dispute (or, as normally referred to, subject to falsification).

The deductive method supported this study. The proposed assertions and discussed aspects support and validate the premises on which our conclusions are based. Thus, the first part of the article is a summary of the Antarctic continent's environmental characteristics and its relevance for environmental balance, as well as its governance system, the ATS. In the second part, a problematization of the matter is proposed by exposing our approach through compatibility of applicable interpretative perspectives and conformity conceived by jurisprudence and practice of foreign relations of international agreements, which renounce, for future effects, the consent of the Legislative Branch, as do EAs. Case examination is carried out in light of the 1988 Brazilian Constitution, as well as considering Brazilian practice in foreign relations and the operability of these Agreements. The conclusion, in turn, reflects the legal basis for the constitutionality of PEPAT's provisions and norms arising therefrom ${ }^{4}$.

\footnotetext{
3 In this article, the term "Executive Agreements" (EA) is used. In Brazilian Portuguese, even though some conceptual differences may be identified, EAs are called "Acordos em Forma Simplificada" ('simplified agreements'). All jurisprudence, legal literature and references were translated into "executive agreements". In the original master thesis, beyond the aforementioned approach the provisions constitutionality is supported by a set of grounding elements, namely: fundamentals of epistemological basis in (International) Environmental Law, fundamentals of principiological basis in (International) Environmental Law and fundamentals of "legal basis", which are a set of technicallegal arguments, such as absence of damage, assumption of environmental issues as Human Rights and environment and justice.
}

\footnotetext{
4 There is no restriction as to the conclusions from this article being applied to other international treaties that establish an "accelerated" form of entry into force of norms by decision of Conference of the Parties (CoP), such as: Article 30 (2) of the Convention on Biological Diversity (1992), Article 16 (3) of the United Nations Framework Convention on Climate Change (1992), Article 10 of The Vienna
} 


\section{THE ANTARCTIC, ITS GOVERNANCE SYSTEM AND PROTOCOL ON ENVIRONMENTAL PROTECTION NORMS}

The Antarctic region, comprising the continent, its islands and the Southern Ocean, is the area south of 60은 South Latitude, according to Article VI of the Antarctic Treaty (AT). The continent is 99.7\% covered with ice, with an approximate area of 13.8 million $\mathrm{km}^{2}$, while the Southern Ocean is formed by the union of water bodies from the Atlantic, Indian and Pacific Oceans, on which are icebergs, ice platforms and floes (Simões 2011).

These natural characteristics raise environmental concerns, and among the most relevant are impacts of climate change in the region. The Antarctic region is essential for atmospheric and oceanic circulation, in addition to being also fundamentally responsible for the dissipation of heat in space. Thus, changes in these environmental dynamics have repercussions that affect local and global environmental balance. In addition to the possible local impacts, which would themselves be absolutely harmful, the effects of climate change in Antarctica would trigger external repercussions; for example, if the impact means melting ice mass, the consequence will be an increase in oceanic levels with catastrophic outcomes on continents and islands of the southern hemisphere, in addition to changes in weather patterns and the occurrence of extreme events, creating different (physical, biological and chemical) socio-environmental repercussions for the entire planet (Aquino F.E., unpublished data, Aquino 2014, Santos, unpublished data).

Convention for the Protection of the Ozone Layer (1985), Article 2(9) of The Montreal Protocol on Substances That Deplete the Ozone Layer (1987), and Article 23 of the United Nations Framework Convention on Climate Change - Paris Agreement (2015/2016).
The Antarctic region is "governed" by an international regime, whose basic foundation is the AT, concluded on December $1^{\text {st }} 1959$ in Washington, with international entry into force on June $23^{\text {rd }} 1961$. The initial signatories were the following countries: Argentina, South Africa, Australia, Belgium, Chile, United States, France, Japan, Norway, New Zealand, United Kingdom and Russia (formerly Soviet Union).

Until the signing of the Treaty in 1959, the region was a target of economic interests that resulted in environmental degradation, especially with the commercial exploitation of whale and seal hunting and political disputes, which materialized in territorial claims and geostrategic attempts of continent use. With the end of World War II and the development of the Cold War, conflicts between North American allies on the continent and the threat of (military) presence of the former Soviet Union on the site led the United States to propose a solution to the "Antarctic problem". After the International Geophysical Year (1957-1959) and a complex process of negotiations, which allowed Soviet presence and excluded other interested countries, the AT was concluded (Chatuverdi 1996, Costa 1959, Villa 2004, Ferreira 2009).

The AT established the region as a peaceful, non-militarized and denuclearized area that should be used for scientific research and cooperation. Article IV, which deals with sovereignty in the region, does not preclude the possibility of territorialization (the claim for territorial sovereignty). The text indicates that sovereignty-claiming States do not need to relinquish their claims. On the other hand, the AT had originally 12 signatories, allowed new accessions (Article XIII, paragraph 1) so much that it expanded its number of acceding States. A system of reciprocal surveillance and inspection was established between the States 
Parties and a body was created among these in order to discuss and develop the AT.

The AT is not a static regime and has evolved toward the Antarctic Treaty System (ATS). According to one of the most traditional concepts, developed by Krasner (1986, p. 2), regimes are a set of "implicit or expressed principles, norms, rules and decision-making procedures around which parties' expectations converge". Regimes are arrangements for cooperation between States, and the ends of which, considering common interests, are the solution for a problematic situation. In a broad sense, the solution to the problem is achieved through the regulation of related activities. In this sense, the ATS regulates activities within the Antarctic region. The ATS is a formal arrangement, made up of binding and non-binding rules ${ }^{5}$. The

5 Besides the Antarctic Treaty (AT), the ATS comprises the Convention for the Conservation of Antarctic Seal (CCAS), signed in London on June $1^{\text {st }} 1972$, with international entry into force on March $11^{\text {th }} 1978$, the Convention of Antarctic Marine Living Resources (CCRVMA), signed in Canberra on May $20^{\text {th }} 1980$, with international entry into force starting on April $7^{\text {th }}$ 1982, the Protocol on Environmental Protection on the Antarctic Treaty (PEPAT) and the Convention on the Regulation of Antarctic Mineral Resource Activities (CRAMRA), signed on June $2^{\text {nd }} 1988$, but never ratified by its signatories and thus not in force. According to Decision 1 of ATCM XIX, Seoul, 1995, the standards and rules produced under the ATS can assume the following configurations: "MEASURES, DECISIONS AND RESOLUTIONS 1. Measures (a) A text which contains provisions intended to be legally binding once it has been approved by all the Antarctic Treaty Consultative Parties will be expressed as a Measure recommended for approval in accordance with paragraph 4 of Article IX of the Antarctic Treaty, and referred to as a "Measure". (b) Measures will be numbered consecutively, followed by the year of adoption. 2. Decisions a) A decision taken at an Antarctic Treaty Consultative Meeting on an internal organizational matter will be operative at adoption or at such other time as may be specified, and will be referred to as a "Decision". (b) Decisions will be numbered consecutively, followed by the year of adoption. 3. Resolutions (a) A hortatory text adopted at an Antarctic Treaty Consultative Meeting will be contained in a Resolution. (b) Resolutions will be numbered consecutively, followed by the year of adoption". Available at:<Antarctic Treaty database - Decision 1 (1995) - ATCM XIX, Seoul (ats.aq)>. Accessed on Aug. $24^{\text {th }}$ 2021. Before 1995, the rules issued by the ATCMs were called recommendations and only had effect after they were internally ratified by the States Parties, pursuant Article IX, paragraphs 1, 4 and 5 of the Antarctic Treaty. Examples of non-binding rules are the following Resolutions: Resolution 3 (2019) - ATCM XLII, about visitor site guidelines assessment and review checklist. Available at: <Antarctic Treaty database - Resolution 3 (2019) - ATCM XLII - CEP XXII, Prague (ats.aq)>. Accessed on Aug. $21^{\text {th }} 2021 \mathrm{em}$ 11/08/2021 and Resolution 5 (2019) - ATCM
ATS's progress through legislation, institutional development and new accessions guarantee its current legitimacy.

Currently, the ATS is composed by 54 States, as they joined the 12 original signatories who have the right to vote. Of the new 42 States, 17 are Consultative Parties (which have the right to vote), since they comply with the provisions in Article IX of the AT, and 25 are Non-Consultative Parties (which do not have the right to vote). ${ }^{6}$ The right to vote is exercised in ATCM forums, that bring together States Parties with the aim of decision-making and regulating activities related to the Antarctic region?

The ATCMs (Article IX) are authorized to make new principled and political propositions. In this sense, some subjects were managed, such as: environment, natural resources, occupation history, scientific research and cooperation, tourism, institutional, logistical and operational matters, exchange of information and legislation. Therefore, it is a dynamic regime, but there are challenges to be overcome, essentially when it comes to relevant concepts

XLII Prague subject reducing plastic pollution in Antarctica and the Southern Ocean. Available at: <Antarctic Treaty database - Resolution 5 (2019) - ATCM XLII - CEP XXII, Prague (ats.aq)>. Accessed on Aug. 21 2021.

6 Precisely, pursuant Article 29 of the Revised Rules of Procedure for the Antarctic Treaty Consultative Meeting, Decision 2 (2016) - ATCM XXXIX, Santiago, Non-Consultive Parties cannot even participate in ATCMs: "29. Non-Consultative Parties are not entitled to participate in the taking of decisions". However, under Article 27 they may be invited to participate in a given ATCM. Available at: <Antarctic Treaty database - Decision 2 (2016) - ATCM XXXIX - CEP XIX, Santiago (ats.aq)>. Accessed on Aug. $11^{\text {th }} 2021$.

7 Among Recommendations, Measures, Decisions and Resolutions, between the years 1961 and 2017, approximately 768 norms were created within the ATS. Of which, 512 are in force. Of all regulations and guidelines, at least 443 reference environmental issues. Of these issues, at least 294 are in force. Of the environmental norms in force: 192 regard specially protected and managed areas, 26 are in respect to environmental protection, 23 deal with monuments, 23 are about fauna and flora, 12 are related to marine living resources, seven regard environmental impact assessment, six are relative to marine pollution and five deal with waste disposal and management. From the 294 environmental norms in force, 240 entered into force after 1995 and 183 are Measures. 
such as that of "peace," "security" and "justice." This is due to a lack of definitive solutions for the future of the continent and because full internationalization is an issue that can bring tension and demands for equality and equity in the region or with emerging principles such as "common heritage", "intergenerational equity" and "sustainable development", which are not part of the instruments nor of the forum agenda (Hemmings 2014). Strategically, the ATS is a distinct regional arrangement, but in the form of a Charter of the United Nations. In the sense that it is not materially or formally part of the United Nations security framework, nevertheless, mirrors in its formation, organization, purposes and values some of the meanings foreseen in the United Nations Charter. Its legitimacy stems from the continuity of accessions and internal developments, the obtaining of the right to vote, the participation of scientific and environmental organizations in the ATCMs, the conclusion of new agreements and legislative and institutional development (Santos, unpublished data).

\section{CONSTITUTIONALITY OF THE MODIFICATIONS TO THE PROTOCOL ON ENVIRONMENTAL PROTECTION \\ Necessary conformations to determine constitutionality}

As mentioned, the constitutionality of some provisions is being examined, namely: Article 9 (3); Annex I, Article 8; Annex II, Article 9; Annex III, Article 13; Annex IV, Article 15; Annex V, Articles 6, 8 and 12; Annex VI, Article 13 (and Schedule, Article 13) all the Protocol on Environmental Protection on the Antarctic Treaty (PEPAT) ${ }^{8}$.

8 At this point, as an example, Article 9, Annex I, and Article 8 on the PEPAT are reproduced: "1. The Annexes to this Protocol shall form an integral part thereof. 2. Annexes, additional to Annexes I-IV, may be adopted and become effective in accordance with Article IX of the Antarctic Treaty. 3. Amendments and modifications
In Brazil, international acts are subject to constitutionality control by the Supreme Federal Court (Article 102, item III, subitem b of the 1988 Brazilian Constitution). As of the Brazilian legal order organization, constitutionality is thought of as being material or formal. In a nutshell, when it is said that there is formal unconstitutionality of a provision, legal norm or treaty, one is considering the existence of a defect in their creation, in turn, when it is said that there is material unconstitutionality, one is considering that the content of the provision, norm or treaty is contrary to the Constitution.

As stated above, neither material nor formal unconstitutionality is identified in the aforementioned provisions. However, in a literal and perfunctory perspective, the acceleration of the entry into force of the amendments to the PEPAT Annexes, in the case of Brazil, without approval by the National Congress, would conflict with the provisions with Article 49 (I) of the Brazilian Constitution: "It is exclusively the competence of the National Congress: I - to decide conclusively on international treaties, agreements or acts which result in charges or commitments that go against the national property" ${ }^{\prime \prime}$ and Article 84 (VIII) of the same document: "The president of the Republic shall

to Annexes may be adopted and become effective in - accordance with Article IX of the Antarctic Treaty, provided that any Annex may itself make provision for amendments and modifications to become effective on an accelerated basis. Annex I: Environmental Impact Assessment". Article 8: Amendment or Modification "1. This Annex may be amended or modified by a measure adopted in accordance with Article IX (1) of the Antarctic Treaty. Unless the measure specifies otherwise, the amendment or modification shall be deemed to have been approved, and shall become effective, one year after the close of the Antarctic Treaty Consultative Meeting at which it was adopted, unless one or more of the Antarctic Treaty Consultative Parties notifies the Depositary, within that period, that it wishes an extension of that period or that it is unable to approve the measure".

9 The expression national property as expressed in Article 49 item I of the 1988 Brazilian Constitution is a broad concept that achieves the universality of goods (movable and real estate) and immaterial assets, monetary assets and rights that measure the economic wealth associated with the sovereign State (Marrara \& Ferraz 2019). 
have the exclusive power to: [...] VIII - conclude international treaties, conventions and acts, ad referendum of the National Congress" (Brazil 2019) ${ }^{10}$.

The circumstantial reading of the provisions reproduced above reinforces the idea that treaty-making power in Brazil is exercised by the Executive Branch (President of the Republic) and by the National Congress (Chamber of Deputies and Federal Senate) to the extent of their powers $^{11}$. Article 84 (VIII) on the 1988 Brazilian Constitution establishes that it would be of exclusive competence of the President of the Republic to conclude (in the sense of making and signing) international arrangements, but that these would not be final until they are submitted and approved by the National Congress. In turn, Article 49 (I) on the Constitution establishes that it is the exclusive competence of the National Congress to decide definitively on international arrangements. This means that for rejection or approval and entry into force of an international arrangement in the domestic legal order, Presidential intervention by means of a veto or sanction is negligible, and its materialization occurs only through publication of a legislative decree, under the terms of the authorization contained in Article 59 (VI) of the 1988 Brazilian Constitution, nevertheless, pragmatically, in the legal order there is the promulgation of a decree of the Executive Branch, confirming the approval of the Treaty by the legislative decree.

In the present case, when examining material constitutionality, firstly, the examination falls directly on Article 9 (3) of the PEPAT. It is in this

10 The text in English of the 1988 Brazilian Constitution used in this article was drawn up by the Supreme Court of Brazil.

11 According to the Supreme Court, treaty-making power undergoes limitations provided for on the Constitution: "No legal value is attributed to the international treaty that, once in the domestic positive legal system, formally or materially infringes the text in the Political Charter" (Brazil 2009). provision that the possibility of amendments or modifications to the Annexes is expected to have an accelerated mechanism of entry into force, which in other words may mean not having them subjected to domestic approval processes of the States Parties, i.e., to Brazilian National congress.

The constitutionality defense stems from the fact that the National Congress itself, when approving the PEPAT, recognized the possibility for amendments or modifications to the Annexes to become compulsory for the country without need for revision ${ }^{12}$. The National Congress understood, if it were the case, to limit its performance in this normative context $^{13}$. On the other hand, it is necessary to emphasize that the wording on the provision is

\footnotetext{
12 The PEPAT and its Annexes entered into force in Brazil due to their approval by Legislative Decree (No. 88/1995) and promulgation by Decree No. 2,472/1998. Arguments, however, are not applicable to Annex VI, which has not been approved by the National Congress. When the PEPAT came into force, Annexes I to IV were already part of the founding text (original set formed by the treaty itself, preamble and annexes I to IV), therefore, they were approved together and entirely. Annex V was adopted in the XVI ATCM (Bonn, 1991) and entered into force in 2002. When the seminal text was submitted to the National Congress, Annex $V$ was included, being, therefore, also expressly ratified by the Country by Legislative Decree n. 88 of 1995. Annex VI is different. It was established under the ATS after their approval and has not been approved by the National Congress to date. I understand that the elaboration of a new Annex to PEPAT is not to be confused with simple alterations to the already approved Annexes, but it needs a specific approval by the National Congress for its inclusion in the national legal system. I emphasize that the text of Measure 1 (2005) - ATCM XXVIII, Stockholm requires the ratification of Annex VI by the AT Parties. Available at: <Antarctic Treaty database - Measure 1 (2005) ATCM XXVIII - CEP VIII, Stockholm (ats.aq)>. Accessed on Aug. $18^{\text {th }} 2021$
}

13 Medeiros (1995, p. 480) explains that this claim may be disputed, for the National Congress secured the "understanding that if the text of a treaty provides for the possibility of it being revised, modified or complemented by adjustments that shall have immediate validity, without the need for fulfillment of all constitutional requirements, it should be added to the legislative decree approving the treaty a precept explicating that the said adjustments should also face National Congress scrutiny". Legislative Decree No. 88 of 1995 attends the necessity of revision by Legislative Branch in case of alteration of the text of the Protocol itself, but not of the Annexes, implicitly agreeing with the provisions of Article 9 (3) of the PEPAT. In this sense, the Legislative Branch correctly, as stated above, agreed whit changes in the Annexes without its consent. Understanding it in a distinct manner implies imposing reservations to the Protocol, which is neither possible nor desirable. 
of authorization, that is, it allows modifications or amendments to the Annexes to adopt an accelerated mechanism of entry into force, so that pragmatically it is in the regarded instrument itself that unconstitutionality may occur. Furthermore, it is necessary to note that this is a consolidated legal norm, with almost 30 years in force without any questioning to these terms - as have other treaties with provisions within the same scope as listed above never been questioned.

In the same vein, in principle, there is no material unconstitutionality in the wording of the Annexes to the PEPAT for the reasons listed above, that is, the Legislative Branch also approved the contents that establish the accelerated form of entry into force of amendments or alterations. Pointing out that in the Brazilian system of constitutionality control, a norm implanted in the national legal order by amendments or modifications may, at any time, have its content analyzed in terms of its constitutionality by the Supreme Federal Court (Article 102, item III, subitem b) and thus any deviation of purpose may be corrected. On the other hand, it should be noted that denying the possibility of accelerated validity of the amendments to the PEPAT annexes, as provided for in the aforementioned Article 9 (3) of the Protocol, implies a possible violation of Article 27 of the Vienna Convention on the Law of Treaties (1969) insofar as the exceptionality of Article 46 of the same Convention could not be invoked because the Legislative Branch itself acquiesced in disregarding its prerogative of definitively deciding on the amendments to the Annexes of the Protocol, with no violation of item II of Article 85 of the Brazilian Constitution ${ }^{14}$.

14 Article 27 of Vienna Convention on the Law of Treaties (1969): "Internal law and observance of treaties: A party may not invoke the provisions of its internal law as justification for its failure to perform a treaty. This rule is without prejudice to article 46". Except
There is also no formal unconstitutionality of the Article 9 (3) of the Protocol, and this is the main aspect to be discussed in this Article. This will be developed in the following topics and rises from the fact that one can conceive of these Annexes modifications and amendments as Executive Agreements (EAs). This term "refers to treaties concluded by the Executive Branch without the consent of the Legislative Branch", being that one of their main characteristics is having a technical character. In these EAs, technical matters are accommodated, which, in general, need updates due to technological, scientific or natural changes, as is the case with environmental issues as those hereby examined. However, for this claim to be proved valid, it is necessary to demonstrate that EAs are admitted by the Brazilian legal order and that those amendments and modifications to the Protocol are types of topics that can be formalized by means of accepted EAs by Brazilian diplomatic practice. Moreover, it should be said that the overcoming of formal constitutionality does not cause any damage to the legal order. In this case, not recognizing formal unconstitutionality of the provisions and adjusting the modifications and amendments of the Annexes to the concept of EA result in their acceptance by the national legal order, regardless of merits about provision

\footnotetext{
for better judgment, in the case under examination, there is no way to reconcile the denial in the provisions of Article 46 of Vienna Convention on the Law of Treaties (1969): "Provisions of internal law regarding competence to conclude treaties 1 . A State may not invoke the fact that its consent to be bound by a treaty has been expressed in violation of a provision of its internal law regarding competence to conclude treaties as invalidating its consent unless that violation was manifest and concerned a rule of its internal law of fundamental importance. 2. A violation is manifest if it would be objectively evident to any State conducting itself in the matter in accordance with normal practice and in good faith". The Vienna Convention on the Law of Treaties entered into force in Brazil on Dec 14th 2009 with Decree No. 7,030. Thus is expressed in Article 85 item II of the Brazilian Constitution: "Those acts of the President of the Republic which attempt on the Federal Constitution and especially on the following, are crimes of malversation: (...) II - the free exercise of the Legislative Power, the Judicial Power, the Public Prosecution and the constitutional Powers of the units of the Federation".
} 
constitutionality. This causes no damage because, as said before, in the Brazilian system of constitutionality control, a norm implanted in the national legal order by amendments or modifications may, at any time, have its content analyzed in terms of its constitutionality by the Supreme Federal Court (Article 102, item III, subitem b).

\section{Executive agreements before and after the Constitution of 1988}

The Constitution of the United States (1787) and the Constitution of France (1791) legally mark the ending of the exclusive will and responsibility of the sovereign with regard to the conclusion of international treaties, now requiring such treaties to be submitted to and controlled by the parliament (Almeida 2013, Gabsch 2010, Medeiros 1995). Since then, in modern democracies, responsibility with respect to concluding international treaties has been shared by the Executive and Legislative Branches. Thus, as asserted by Almeida (2013, p. 162), "the division of powers between executive and legislative branches has therefore ruled the treaty-making power"15. These are the treaties signed in solemn form, i.e., which require parliamentary consent.

However, in a particular and restricted sphere of action, the possibility of concluding in the sense of generating internal and external effects - international arrangements within the sole scope of the Executive Branch remained accepted to agreements that do not require the assent of the Legislative Branch (Rezek 2013). For Medeiros (1995, p. 209), EAs are "in general, bilateral treaties that apply immediately without legislature approval and without ratification concluded by negotiators acting on behalf of the State". Speed of conclusion, its technical characteristics, confidentiality and the vast

15 Treaty making-power "is the competence of States constitutive powers to make and to declare this government's will to assume international commitments", differently from treaty-making capacity, which is the States' capacity to conclude treaties (Medeiros 1995, p.136). number of contractual phenomena are reasons for concluding EAs (Mazzuoli 2014).

The fundamental point in this contextualization is the Constitution of Belgium (1831), which, in its Article 68, alluded to the possibility of some treaties being concluded directly and exclusively by the Executive Branch; however, others should necessarily be submitted to parliamentary approval, such as treaties related to public finances, trade and those that generated obligations to the population (Medeiros 1995). As explained by Gabsch (2010) and Rezek (2013), a restrictive interpretation of the word 'treaty' led to the idea and consequential practice that not all international arrangements required consent from the Legislative Branch. International arrangements called 'agreements' or 'executive agreements' are restricted to three categories:

"those that are based in guidelines or prior authorization from congress; those that are only executed after authorization from the congress; and those deriving from strict constitutional powers of the Executive" (Rezek 2013, p. 42-43).

Thus, different constitutions, extraconstitutional legislations or even legal practices from different countries - such as Spain, England, Netherlands, Argentina, Venezuela, India, South Africa, Austria, Greece, Italy, Switzerland and Portugal - have made it possible, in different circumstances, to conclude agreements in the form of EAs as a way to share competences between the Executive and Legislative Branches in relation to international commitments (Rezek 2013, Gabsch 2010).

In Brazil, the issue is controversial. Throughout the validity of republican constitutions, constitutional reception of this modality of conclusion and implementation of international arrangements has always been discussed. Republican constitutions of 1891, 1934, 1937, 1946 and 1967, yet with different wordings, were not explicit as to the possibility 
of concluding EAs; in turn, in a broad sense, they manifested the need to submit international treaties to congress. Notwithstanding, according to Medeiros (1995), during the terms of these constitutions, regardless of the controversy over the constitutionality of such possibility, several agreements in the form of EAs were signed by Brazil - at least seven with different themes and formats were identified.

Even after the promulgation of the 1988 Brazilian Constitution, the possibility for Brazil to conclude EAs remained controversial. According to Medeiros (1995, p. 383), the wording of the constitutional provisions relating to the matter (Article 49, I, and Article 84, VIII) did not settle discussions in the legal literature: "Effectively, the 1988 Constitution lost the opportunity to discipline in a modern and clear way as to the competence to conclude treaties and further expanded the controversy over the topic"16.

Nevertheless, the defense of Brazil's possibility to conclude agreements in a simplified form stems, in general, from the following arguments. The central one is that combining the interpretation of Article 49 (I) and Article 84 (VIII) to the 1988 Constitution, National Congress competence would be restricted to international treaties, agreements or acts which entail serious commitments to national property, so that all others could be limited to a procedure completed exclusively by the Executive Branch.

In the defense that submission to the Legislative Branch was restricted to international treaties and acts when these "carry burdensome charges and commitments to the national heritage', in the form of Article 49 item I of the Brazilian Constitution, José Sette Câmara's

16 Medeiros (1995) listed authors who defended that all signed international arrangements should be submitted to the Legislative Branch. In summary, arguments in this line of thought are supported by the notion of a comprehensive interpretation of Article 84 (VIII) and a restricted interpretation of Article 49 (I), in which the latter would not have the power to limit the scope of the first. Nevertheless, there is an expressive number of authors, yet in different contexts, lengths and motivations, who admit that certain treaties, among which EAs, may be concluded by the Executive Branch without consent of the Legislative. position is the most extreme as founded on the precept of inclusio unius exclusio alterius (Medeiros, 1985 p. 387). In turn, Cançado Trindade, endorsing the arguments developed by José Sette Câmara and joining Hildebrando Accioly's internationalist thought, as Medeiros (1995), added a new argument in the following order:

(...) while article 84, VIII, of the 1988 Brazilian Constitution refers to "international treaties, conventions and acts", Article 49, item I, speaks of "international treaties, agreements or acts that entail burdensome charges or commitments to national heritage". Thus, the constituents of 1988, when inserting in Article 49, item I, of the Brazilian Constitution the expression international acts preceded by or, would have had in mind the international acts comparable in their subject and substance to the treaties and conventions, and evidently not any and all expedient of the Ministry of Foreign Affairs in its written contacts with the Chanceries of other countries (Medeiros 1995, p. 388).

In addition to constitutional interpretation, it is necessary to observe other relevant factors in understanding Brazilian admission of EAs. For Medeiros (1995), international arrangements should be submitted to the National Congress, but an old practice of concluding EAs in Brazil subsists:

In practice, however, two types of processes are used in Brazil for the signing of international treaties: the complete process, which comprises the stages of negotiation, signature, message to congress, parliamentary approval, ratification and promulgation (or, when applicable, message to congress, approval, adhesion and promulgation), and the 
abbreviated process, which comprises the stages of negotiation, signature or exchange of notes and publication (Medeiros 1995, p. 172, 479-480).

Almeida (2013, p.177-178) goes in the same direction, asserting that the reasons for accepting the possibility of adopting EAs come from Brazilian praxis. According to this author, for the Brazilian Ministry of Foreign Affairs, some treaties do not require Legislative Branch approval: "These are treaties concluded by means of exchange of notes or other format which have been authorized by or constitute the implementation of a previous one that was duly approved, and which does not modify it". Also, for Almeida (2013), Brazilian practice recognizes the conclusion of EAs and this entails considering them a custom and that this is a rule of law in domestic and international orders. Moreover, it should be noted that this practice was not interrupted by the promulgation of the 1988 Constitution ${ }^{17}$.

Another relevant conclusion which can be observed over the years of EA admission practice in Brazil is that of the tacit acquiescence by the Legislative Branch in relation to the matter, as explained:

Brazilian executive branch based this practice on constitutional provisions, not having the legislative branch protested to ensure respect for its constitutional prerogatives. The necessary elements for custom rule configuration, thus, rest confirmed (Almeida 2013, p. 177-178).

For Gabsch (2010), the silent acquiescence from the Legislative Branch was also crucial for assuming the hypothesis of EA constitutionality. Finally, it should be noted that the Manual of Procedures for Brazilian Diplomacy (Brazil 2010,

17 Between 1988 and 1993, 182 such agreements were concluded, among which were those that aimed at operationalizing international arrangements previously approved by the National Congress (Medeiros 1995). A publication by the Ministry of Foreign Affairs accounts for 300 EAs signed annually by the country (Almeida 2013). p. 7-8) confirms all these considerations in the legal literature by officially ratifying the possibility for Brazil conclude agreements in a simplified form: "According to Brazilian diplomatic practice, agreements may be concluded in a simplified form, based on Art. 84, item VII, of the Federal Constitution".

Based on the arguments listed above, the possibility for Brazil to enter into agreements in a simplified form is admitted ${ }^{18}$. It is then paramount to verify which types of agreements in simplified form would be acceptable and whether the amendments to the PEPAT's Annexes meet these possibilities.

\section{The typology of Executive Agreements in Brazil and their adaptation to PEPAT's Annexes}

The Manual of Procedures for Brazilian Diplomacy (Brazil 2010, p. 7-8), in addition to officially confirming the possibility for Brazil to conclude EAs specifies types of arrangements that may be concluded by the country in form of EA, "provided they do not entail an increase in public expenditure, as the resources for their implementation have to be foreseen as budget previously approved by law", among such agreements are:

complementary acts to a treaty, basic agreements or framework agreements, previously approved by the National Congress, intended for the implementation of the agreed matter, for the interpretation of its provisions or for term extension, such as complementary arrangements, executive programs or additional protocols ${ }^{19}$ (Brazil 2010, p. 7-8).

\footnotetext{
18 The fact that concluding agreements as EAs in Brazil is a possibility does not entail that legislative imprecision is not recognized or that the need for constitutional and/or legal modifications to rule these agreements' use is disregarded. Certainly, National Congress resignation or sublimation in taking part of the process of concluding EAs is not the best solution for the issue.

19 The Manual of Procedures for Brazilian Diplomacy (Brazil 2010, p. 7-8) also claims that "will not be considered EAs those acts which: contain commitments about matters of great technological, scientific,
} 
The Manual (Brazil 2010, p. 7-8) also clarifies that agreements in the form of EAs "designate less formal agreements than treaties, or complementary agreements to a treaty or convention, or even interpretive agreements from a previous act. It can also designate the conclusion or final report of an international conference". It is therefore necessary to analyze the object of this topic in view of these concepts.

Firstly, when classifying international arrangements according to their typology, the Manual of Procedures (Brazil 2010, p. 7) states that Brazil has used the term 'Agreement' in "bilateral negotiations of political, economic, commercial, cultural, scientific and technical natures. This denomination admits several developments, among which are framework agreement or basic agreement, "also known as an 'umbrella'[treaty], which are international treaties that establish a general framework of cooperation and "should be complemented by subsequent instruments, such as Complementary Arrangements or Executive Programs, that implement their broad provisions on a concrete level".

It is evident that the PEPAT perfectly meets the idea of a complementary framework for the AT (here the framework treaty or framework agreement) because it regulates, in general, aspects related to the environment of the Antarctic continent, which is one of its objectives. The PEPAT also fits in the context of "complementary acts to a treaty, basic agreements or framework agreements, previously approved by the National Congress, intended for the implementation of the agreed material, for the interpretation of its provisions", precisely within the concept of "additional protocols". Thus, the Protocol could, as it did,

environmental, economic or political relevance to Brazilian society; contain provisions of direct or indirect fiscal nature or serious commitments to national property that have not been previously authorized by law; implicate changes in Brazilian legislation; entail onus or serious commitments to national property or generate obligations to the State in the context of international law; modify or revise commitments, rights, obligations and duties described in international acts approved by the National Congress". discipline in order to establish a simplified process for the entry into force of the technical norms provided for in its Annexes. Although, it can be said that "protocols" can be conceived within the scope of EAs as part of a framework treaty, which would be in the case of the AT, this question is not relevant since, as mentioned, the PEPAT itself was approved by the National Congress.

In relation to the second concept, the amendments and modifications in the Protocol's Annexes are perfectly within the concept of "complementary acts" to a framework treaty or agreement previously approved by the National Congress, whether we consider the PEPAT itself or the AT as a framework treaty or agreement, due to their purpose of implementing, detailing or normatizing the agreed matter or interpreting its provisions.

Finally, although it is not possible in this case to conceive of the amendments and modifications in the PEPAT's Annexes as commitments of relative or secondary importance, which is one of the characteristics of the "complementary acts", the fundamental question is that in this hypothesis they are intended to complement and implement another international arrangement previously concluded or to regiment technical issues, as required by the concept. This construction brings the idea of complementary arrangement closer to that of the PEPAT's Annexes, and, according to Varella (2010, p. 39) the "annex aims to make the treaty lighter, removing provisions, details, numbers and percentages that hinder comprehension". Nevertheless, the content of the annex is as mandatory as the content of the arrangement.

It is also imperative to examine whether the norms produced under the terms of these provisions effectively and teleologically meet the idea of a technical and complementary legal repository, with the purpose of implementing the agreed matter provided for in the Protocol. Thus, from the total environmental norms in force in ATS, 183 are Measures, and 170 of which are related 
to (the designation and regulation of) specially protected and managed areas. These are the Antarctic Specially Protected Area (ASPA) and the Antarctic Specially Managed Areas (ASMAs) ${ }^{20}$. ASPAs and ASMAs are created and/or managed by Measures as stipulated in the PEPAT's Annex V. This, in turn, establishes in its Article 6 that an area Management Plan may come into force 90 days after its approval at the ATCM in which they were adopted. Still, both ASMAs and ASPAs clearly materialize conservation ideas in the Antarctic environment. For example, ASPA No. 101 (Taylor Rookery, Mac. Robertson Land) was primarily designated as such for being an area with important or unusual species, including the main breeding colonies of native birds and mammals. In this ASPA, there is a colony of emperor penguins, "the largest of this species' only two colonies located entirely on land". The colony has been monitored since $1954^{21}$. Through Measure 1 (2015), which was adopted at ATCM XXXVIII, in Sofia, in June 2015 and which came into force on October 10th 2015, this ASPA had its Management Plan revised. Therefore, it is undoubtable that the rules resulting from the aforementioned provisions are of technical nature, complementary to the AT and the PEPAT resolutions and materialize the implementation of the agreed matter. This information also demonstrates the effectiveness and compliance resulting from the provisions that accelerate the entry into force of environmental norms in the regulatory context of the ATS.

20 ASPAs are geographically limited areas in the Antarctic region, instituted for the purpose of protecting scientific, aesthetic, historical or natural values, as well as for the combination of these purposes or planned and current scientific research. ASMAs are geographically limited areas in the Antarctic region, instituted as they demonstrate relevant scientific, aesthetic, historical or natural characteristics and to facilitate the planning and coordination of local activities, avoiding potential conflicts, improving cooperation and reducing environmental impact.

\section{CONCLUSIONS}

The Antarctic Continent is of fundamental relevance for the planet's environmental balance. This has even greater repercussions when the effects of climate change and its resulting domestic and international impacts are associated with these environmental characteristics.

It is also necessary to endorse the importance of the Antarctic Treaty System (ATS) and its evolving legislative and decision-making instruments as essential for environmental preservation. This way, it should be reiterated that the provisions, as well as norms resulting therefrom are constitutional and must be accepted in the domestic legal order.

Considering that the hypothesis was controlled, the entirety of this article leads to the constitutionality of the provisions examined, namely: Article 9 (3); Article 8 in Annex I, Article 9 in Annex II, Article 13 in Annex III, Article 15 in Annex IV; Articles 6, 8 and 12 in Annex V, Article 13 in Annex $V$ and Article 13 in Schedule, all of the Protocol on Environmental Protection on the Antarctic Treaty (PEPAT), as stated previously. There is neither material nor formal unconstitutionality. Formal unconstitutionality, in the specific case of Article 9 (3) of the PEPAT, is rejected due to approval of the treaty by the National Congress itself and because the content of the accelerated entry into force of amendments and modifications is authorizing and has not faced controversy in almost 30 years. In turn, there is no material unconstitutionality because the amendments and modifications proposed in the Protocol's Annexes can be considered Executive Agreements (EAs), which are admitted as constitutional in Brazil with support of constitutional interpretation, doctrinal lessons, formal recognition of the legislation and its extensive use within Brazilian practice in foreign affairs.

21 Available at: http://www.ats.aq/devPH/apa/ep_protected_ detail.aspx?type=2\&id=6\&lang=e. Accessed on Sept. $12^{\text {th, } 2017}$. 


\section{REFERENCES}

ALMEIDA PW. 2013. A Tendência de Conclusão dos Acordos em Forma Simplificada: Evolução e Prática Brasileira. Rev Secr Trib Perm Revis 1: 161-164. https://doi.org/10.16890/ rstpr.a1.n1.161.

AQUINO FE. 2014. A Antártica e o Clima no Rio Grande do Sul. In: Nastari A (Ed), Antártica 2048: Mudanças Climáticas e Equilíbrio Global, São Paulo: Marina Books, 66-73 p.

BRAZIL. 2009. Decree No. 7,030, of Dec. $14^{\text {th }}, 2009$. Available at: Decreto no 7030 (planalto.gov.br). Accessed on Aug. $18^{\text {th }} 2021$.

BRAZIL. 2010. Ministry of Foreign Affairs. Atos Internacionais. Prática Diplomática Brasileira. Manual de Procedimentos. Divisão de Atos Internacionais. Brasília, $20 \mathrm{p}$.

BRAZIL. 2019. Supreme Court. Constitution of the Federative Republic of Brazil (CFRB). Constitutional text enacted on October 5, 1988. Available at: http://www. stf.jus.br/arquivo/cms/legislacaoConstituicao/anexo/ brazil_federal_constitution.pdf. Accessed on Feb. $12^{\text {th }}$ 2021.

CHATUVERDI S. 1996. The Polar Regions: a political geography. Chichester: John Wiley \& Sons, 30 p.

COSTA JF. 1959. Antártida: o problema político (III). Rev Bras Polit Int 5: 79-89.

FERREIRA FRG. 2009. O Sistema do Tratado da Antártica: Evolução do Regime e seu Impacto na Política Externa Brasileira. Brasília: Fundação Alexandre Gusmão, 248 p.

GABSCH RDA. 2010. Aprovação de tratados internacionais pelo Brasil: possíveis opções para acelerar seu processo. Brasilia: FUNAG, 280 p.

HEMMINGS AD. 2014. Re-justifying the Antarctic Treaty System for the 21st century: rights, expectations, and global equity. In: Powell RC \& Dodds K (Eds), Polar Geopolitics? Knowledges, Resources and Legal Regimes, Cheltenham, Northampton: Edward Elgar Publishing Limited, 55-73 p.

KRASNER SD. 1986. Structural causes and regime consequences: regimes as intervening variables. In: Krasner SD (Ed), International Regimes, Ithaca: Cornell University Press, 1-21 $\mathrm{p}$.

MARRARA T \& FERRAZ L. 2019. Direito Administrativo dos Bens (Parte I). In: Tratado de Direito Administrativo. v. 3. Di Pietro MSZ (Ed), Thomson Reuters Brasil. RB-1.11. Available at <https://proview.thomsonreuters.com/title. html?redirect=true\&titleKey=rt\%2Fmonografias\%2F1009 $64044 \% 2 F v 2.1 \&$ titleStage $=F \&$ titleAcct $=i a 744803 f 0000015$ 43973e63b2ec63f42\#sl=0\&eid=d9fedffffda0e08da5ac0db 32b5dd7c4\&eat=\%5Bereid\%3D\%22d9fedffffda0e08da5a
c0db32b5dd7c4\%22\%5D\&pg=RB-1.1\&psl=p\&nvgS=false $>$. Accessed on Aug. 24 2021.

MEDEIROS APC. 1995. O Poder de Celebrar Tratados: Competência dos poderes constituídos para celebração de tratados, à luz do Direito Internacional, do Direito Comparado e do Direito Constitucional Brasileiro. Porto Alegre: Sérgio Antônio Fabris Editor, 624 p.

REZEK JF. 2013. Parlamento e Tratados Internacionais: o modelo constitucional do Brasil. Rev Dir Fund Dem 14: 40-72.

SIMÕES JC. 2011. O ambiente antártico: domínio de extremos. In: Goldenber J (Ed), Antártica e as Mudanças Climáticas Globais: um desafio para humanidade, São Paulo: Editora Edgard Blücher, 15-27 p.

VARELLA MD. 2010. Direito Internacional Público. São Paulo: Saraiva, 478 p.

VILLA RD. 2004. A Antártida no Sistema Internacional: análise das relações entre atores estatais e não-estatais com base na perspectiva da questão ambiental. São Paulo: Editora Hucitec, 168 p.

\section{How to cite}

SANTOS LEF. 2021. Constitutionality analysis of amendments to the Protocol on Environmental Protection on the Antarctic Treaty Annexes. An Acad Bras Cienc 94: e20210385. DOI 10.1590/0001-3765202120210385.

\section{Manuscript received on March 17, 2021; \\ accepted for publication on September 7, 2021}

\section{LEO EVANDRO FIGUEIREDO DOS SANTOS}

https://orcid.org/0000-0002-0050-5119

Federal University of Rio Grande do Sul, Polar Climate Center, 9500 Bento Gonçalves Ave, Building 43136, Rooms 207 and 210, Agronomia, 91501-970 Porto Alegre, RS, Brazil E-mail:leoefs@gmail.com

\section{(cc) BY}

